\title{
УРОКИ СУДЕБНОЙ ПРАКТИКИ РАСПРОСТРАНЕНИЯ ПОЛОЖЕНИЙ СТ. 76.2 УК РФ НА КАТЕГОРИЮ ТЯЖКИХ ПРЕСТУПЛЕНИЙ
}

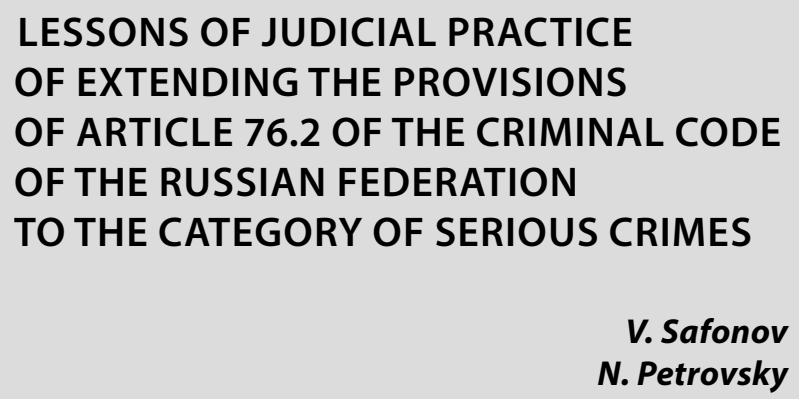

LESSONS OF JUDICIAL PRACTICE

OF EXTENDING THE PROVISIONS

OF ARTICLE 76.2 OF THE CRIMINAL CODE OF THE RUSSIAN FEDERATION TO THE CATEGORY OF SERIOUS CRIMES

V. Safonov

N. Petrovsky

Summary. The article analyzes the trend of judicial practice in applying the provisions of the Criminal Code of the Russian Federation on exemption from criminal liability with the imposition of a court fine (Article 76.2 of the Criminal Code of the Russian Federation) of persons who have committed a serious crime. It is stated that the procedural decision to release a person who has committed a serious crime from responsibility is preceded by a change by the courts of the category of crime to the category of medium gravity. The absence of a single procedural form of the final procedural document is revealed, since in some cases the decision to release from criminal responsibility is taken by the courts in the form of a sentence, in others - by a court decision. The thesis about the inconsistency of such practice with the requirements of substantive and procedural law is substantiated. It is concluded that the provisions of Article 76.2 of the Criminal Code of the Russian Federation should not be extended to the category of serious crimes due to the contradiction to the constitutional principle of separation of powers, the criminal law principles of legality and justice. The necessity of excluding Part 6 of Article 15 of the Criminal Code from the Criminal Code of the Russian Federation is justified.

Keywords: exemption from criminal liability; judicial fine; categories of crimes; change in the category of crime; the principle of legality; the principle of justice.
$\Phi$ едеральным законом от 03.07.2016 № 323-Ф3 «О внесении изменений в Уголовный кодекс Российской Федерации и Уголовно-процессуальный кодекс Российской Федерации по вопросам совершенствования оснований и порядка освобождения от уголовной ответственности» от 03.07.2016 г. глава 11 УК РФ дополнена статьей 76.2 УК РФ (Освобождение от уголовной ответственности с назначением судебного штрафа), раздел VI УК дополнен главой 15.2 (Судебный штраф). Этим же законом в главу 4 УПК РФ включена статья 25.1 УПК РФ (Прекращение уголовного дела или уголовного преследования в связи с назначением
Сафонов Владимир Николаевич

К.ю.н., доцент, Северо-Западный филиал ФГБОУВО «Российский государственный университет правосудия» (Санкт-Петербург); федеральный судья

(в отставке)

svn205@gmail.com

Петровский Николай Казимирович

К.ю.н., дочент, адвокат, Санкт-Петербургская городская коллегия адвокатов, АК № 52

pnkspb5@mail.ru

Аннотация. В статье предпринят анализ тенденции судебной практики применения положений Уголовного кодекса Российской Федерации 06 освобождении от уголовной ответственности с назначением судебного штрафа (ст. 76.2 УК РФ) лиц, совершивших тяжкое преступление. Констатируется, что процессуальному решению об освобождении лица, совершившего тяжкое преступление от ответственности предшествует изменение судами категории преступления на категорию средней тяжести. Выявлено отсутствие единства процессуальной формы окончательного процессуального документа, поскольку в одних случаях решение об освобождении от уголовной ответственности принимается судами в форме приговора, в других - постановлением суда. Обосновывается тезис о несоответствии подобной практики предписаниям материального и процессуального права. Делается вывод о недопустимости распространения положений ст. 76.2 УК РФ на категорию тяжких преступлений ввиду противоречия конституционному принципу разделения властей, уголовно-правовым принципам законности и справедливости. Обосновывается необходимость исключения из УК РФ ч. 6 ст. 15 УК РФ.

Ключевые слова: освобождение от уголовной ответственности; судебный штраф; категории преступлений; изменение категории преступления; принцип законности; принцип справедливости.

меры уголовно-правового характера в виде судебного штрафа).

За прошедшие пять лет институт судебного штрафа подтвердил свою жизнеспособность и востребованность в правоприменительной практике [15]. Так, в 2018 г. судебный штраф был назначен 32050 лицам, в 2019 г. 51213 обвиняемым, а в 2020 г. уже 57957 лицам [25]. Совершенно очевидный рост числа судебных решений об избрании этой меры уголовно - правового характера в 2019 и 2020 г.г. по сравнению с предыдущими отчётными (в статистическом отношении) периода- 
ми легко находит своё объяснение. Во-первых, и правоприменители, и адресаты процессуальных решений успели оценить преимущества подобного варианта решения с материально - и процессуально - правовой точек зрения; во-вторых, многие накопившиеся вопросы о возможности применения положений ст. 76.2 УК РФ были сняты разъяснениями, данными в обзоре судебной практики освобождения от уголовной ответственности с назначением судебного штрафа (статья 76.2 УК РФ), утверждённом Президиумом Верховного Суда РФ 10 июля 2019 г. (далее - ВС РФ) [15].

Думается, что средний показатель применения норм этого института останется на достаточно высоком уровне, что объясняется рядом факторов. Освобождение от уголовной ответственности в соответствии со ст. 76.2 УК РФ хотя и относится к нереабилитирующим основаниям, но имеет свои очевидные для лица, привлекаемого к уголовной ответственности, достоинства. А именно: оно не будет иметь судимости, что позволяет ему избежать негативных последствий, связанных с наличием судимости. Добавим сюда «выгоды» стороны обвинения: 1) снижение рисков, связанных с судебной перспективой; 2) преференции статистического плана; 3) банальная «производственная» популярность, в основе которой - процессуальный «минимализм», т.е. сведённые до минимума процессуальные затраты с точки зрения объёма доказательств, а также усилий и времени по их оформлению.

Учитывая востребованность следственно - судебной практикой применения положений ст. 76.2 УК РФ, можно предположить возможные варианты её расширения за счёт 1) очевидных достоинств рассматриваемого правового основания разрешения дела по существу с учётом широкого понимания вариантов позитивного посткриминального поведения в духе упомянутого выше обзора ВС РФ; 2) абсолютного или относительного роста числа преступлений небольшой и/или средней тяжести; 3) расширения практики применения положений ч. 6 ст. 15 УК РФ к категории тяжких преступлений, с последующим применением положений ст. 76.2 УК РФ.

Два первых основания расширения практики применения ст. 76.2 УК РФ существенных проблем не обнаруживают. Иное дело, когда расширение сферы действия ст. 76.2 УК РФ осуществляется через неоднозначно комментируемые в научной литературе положения ч. 6 ст. 15 УК РФ. Рассмотрим возможность применения ст. 76.2 УК РФ по последнему из упомянутых нами механизмов.

Судебный штраф представляет собой денежное взыскание, назначаемое судом при освобождении лица от уголовной ответственности, и может быть применен к лицу, впервые совершившему преступление небольшой или средней тяжести, в случае если оно возместило ущерб или иным образом загладило причиненный преступлением вред (статья 76.2 и часть первая статьи 104.4 УК РФ). Процессуальный порядок производства о назначении меры уголовно-правового характера в виде судебного штрафа при освобождении от уголовной ответственности предусмотрен главой 51.1 УПК РФ в числе прочего он предполагает, что решение о прекращении уголовного дела или уголовного преследования в связи с назначением меры уголовно-правового характера в виде судебного штрафа может быть принято судом как в ходе досудебного производства по уголовному делу по ходатайству, поданному следователем с согласия руководителя следственного органа, либо дознавателем с согласия прокурора, так и в ходе судебного производства по уголовному делу, при наличии оснований, предусмотренных статьей 25.1 УПК РФ.

Однако остается открытым вопрос о возможности применения положений ст. 76.2 УК РФ к категории тяжких преступлений. И какова при этом процедура? Казалось бы, постановка такого вопроса исключается, ведь в соответствии со ст. 76.2 УК РФ освобождение от уголовной ответственности с назначением судебного штрафа ограничено категориями преступлений небольшой или средней тяжести. «Экспансия» рассматриваемого основания освобождения от уголовной ответственности в сферу категории тяжких преступлений, казалось бы, ограничивается и положениями ч. 6 ст. 15 УК РФ, позволяющей изменить категорию преступлений на более мягкую лишь при постановлении приговора с назначением наказания.

Обусловлено это тем, что в общей концепции теории уголовного и уголовного процессуального права РФ принято полагать, что освобождение от уголовной ответственности может быть оформлено в виде постановления, но не приговора.

Исходя из отчета Судебного департамента при Верховном Суде Российской Федерации («О работе судов общей юрисдикции по рассмотрению уголовных дел по первой инстанции за 12 месяцев 2020 г.»), положения ст. 76.2 УК РФ применялись к категории тяжких преступлений 38 раз [25]. Изучение самой этой практики обнаруживает два подхода: изменение категории преступления с последующим освобождением от уголовной ответственности по рассматриваемому основанию осуществлялось посредством вынесения судами постановления или приговора.

Так, постановлением Пятигорского городского суда от 13 июля 2020 года гражданке Р., обвиняемой по ч. 3 
ст. 160 УК РФ, изменена категория преступления с тяжкого на категорию преступления средней тяжести и назначена мера уголовно-правового характера в виде судебного штрафа в размере 100000 рублей [27]. Акцентируем внимание на том, что результирующим документом в этом деле стало именно постановление суда, а не приговор.

Несложно заметить, что в данном процессуальном решении необычным образом пересеклись два уголовно-правовых института: судебного штрафа, как вида освобождения от уголовной ответственности; и категориальности преступлений. Необычность заключается, во-первых, в применении положений ст. 76.2 УК РФ к категории тяжких преступлений, что, казалось бы, по определению недопустимо, а, во-вторых, в изменении категории преступления с существенными отступлениями от правил ч. 6 ст. 15 УК РФ, то есть посредством вынесения постановления, что естественно, не связано с предварительным определением наказания.

В другой ситуации Кронштадтский районный суд Санкт-Петербурга, применяя положения чт. 76.2 УК РФ, прибег к ранее не применявшейся правовой конструкции. Так, приговором от 25.02.2020 г. этот суд признал гр. Н. виновным в совершении преступления, предусмотренного ч. 1.2 ст. 263 УК РФ, назначил ему наказание в виде трех лет лишения свободы с лишением права заниматься определенной деятельностью, связанной с управлением транспортными средствами, на срок один год шесть месяцев. На основании ст. 73 УК РФ назначенное Н. основное наказание в виде лишения свободы суд постановил считать условным с испытательным сроком на два года с соответствующими обязанностями, регламентированными этой нормой. А далее суд в соответствии с ч. 6 ст. 15 УК РФ изменил категорию преступления, совершенного Н., с тяжкого на категорию преступления средней тяжести и на основании ст. 76.2 УК РФ освободил осуждённого Н. от наказания, в связи с применением меры уголовно-правового характера в виде судебного штрафа в размере тридцати тысяч рублей [28].

Строго говоря, суд в этом случае применил не предусмотренный законом механизм освобождения от наказания, поскольку назначение судебного штрафа может быть только альтернативой освобождения от уголовной ответственности, а не от наказания.

Не является подобная процессуальная форма вариантом освобождения от уголовной ответственности как отказа от осуждения виновного лица.

Таким образом, в двух описанных нами случаях суды весьма радикально преодолевали сложившиеся пра- вовые конструкции и процессуальные формы, распространяя положения ст. 76.2 УК РФ на «несвойственные» этой норме стадию уголовного процесса и категорию преступления.

В контексте рассматриваемой проблемы для нас важным является не только неоднозначное преодоление судами правовых предписаний и процессуальных форм, но и характер посягательства с учётом важности объекта правовой охраны.

Так, 15 мая 2020 г. приговором Благоварского межрайонного суда Республики Башкортостан гражданин Л., признан виновным в совершении преступления, предусмотренного ч. 1 ст. 111 УК РФ, ему назначено наказание по этой статье в виде 2 лет 6 месяцев лишения свободы условно с испытательным сроком 3 года, которое, как и в предыдущем случае, на основании ст. 76.2 УК РФ заменено мерой уголовно - правового характера в виде судебного штрафа в размере 10000 (десять тысяч) рублей [16]. Не может не обращать на себя внимание то обстоятельство, что от уголовной ответственности освобождено лицо, умышленно причинившее тяжкий вред здоровью потерпевшего - наиболее важному и строго охраняемому объекту уголовно-правовой охраны.

Мы не случайно употребили слово «заменено», ибо легально рассматриваемый механизм применения ст. 76.2 после назначенного судом по приговору суда наказания в УК РФ не предусмотрен.

В научной литературе исследователями-криминалистами приводятся подобные примеры в качестве аргумента несостоятельности положений ч. 6 ст. 15 УК РФ с момента принятия этой новеллы законодателем, а в дальнейшей её «связке» с положениями УК РФ об освобождении от уголовной ответственности эта норма и вовсе стала объектом «прицельного огня». Например, А.М. Репьева, исследуя складывающуюся практику изменения категорий преступлений с позиций соответствия её принципу справедливости, со ссылкой на В.И. Решетняка, приводит такой пример:

Красносулинским районным судом Ростовской области установлено, что Б. нанесла ножом своему гражданскому мужу Т. два удара в грудную клетку, причинив ему телесные повреждения в виде проникающего колото-резаного ранения с повреждением левого легкого с гемотораксом, т.е. тяжкий вред, причиненный здоровью человека, по признаку опасности для жизни. Суд признал Б. виновной в совершении преступления, предусмотренного ч. 1 ст. 111 УК, и назначил наказание в виде 2 лет лишения свободы. На основании ст. 73 УК РФ назначенное наказание постановлено считать 
условным с испытательным сроком 6 месяцев. В соответствии с ч. 6 ст. 15 УК РФ суд изменил категорию преступления с тяжкого на преступление средней тяжести и на основании ст. 76 УК РФ освободил осужденную Б. от отбывания назначенного наказания в виде 2 лет лишения свободы с применением ст. 73 УК РФ за примирением сторон [22].

Этот факт правоприменения вызывает ряд вопроCOB:

1. Почему умышленное причинение вреда здоровью человека в виде проникающего колото-резаного ранения с повреждением левого легкого с гемотораксом, с применением ножа квалифицируется по ч. 1 ст. 111 УК РФ, а не по п. «з» ч. 2 ст. 111 УК РФ (умышленное причинение тяжкого вреда здоровью, опасного для жизни человека, с применением оружия или предметов, используемых в качестве оружия), что напрашивается, исходя из фактических обстоятельств дела?

2. Не связано ли это с тем, что квалификация действий Б. по «з» ч. 2 ст. 111 УК РФ лишила бы правоприменителя перспективы изменения категории преступления на категорию средней тяжести с последующим освобождением от уголовной ответственности, так как в этом случае принадлежность деяния к особо тяжким исключала бы возможность освобождения от уголовной ответственности по причине непреодолимой разницы в тяжести деяний в две ступени?

К сожалению, страничка этого дела на официальном сайте Красносулинского районного суда содержит лишь статистическую информацию, а сам приговор на ней не размещён [29]. Однако в основных фактических обстоятельствах не приходится сомневаться, так как В.И. Решетняк - не только учёный-криминалист, но на то время и судья Ростовского областного суда, имевший доступ к материалам дела.

В приведённых случаях (а они, как показывают литературные источники - не единичные) мы наблюдаем примеры радикального применения правовых норм, понять природу и механизм использования которых исследователю непросто. Да и среди судей, опрошенных авторами настоящей работы, нет единства в вопросе о возможности применения в определённых ситуациях положений ст. 76.2 УК РФ и тем более - в её взаимосвязи с ч. 6 ст. 15 УК РФ. Встречаются ситуации, когда одни судьи относительно широко практикуют применение ст. 76.2 УК РФ, реже - в её взаимосвязи с ч. 6 ст. 15 УК РФ, другие - крайне осторожно применяют положения ст. 76.2 УК РФ и не приемлют эту норму как следующий после обращения к ч. 6 ст. 15 УК РФ правоприменительный этап.
Характерна избирательность апелляционных инстанций к рассматриваемой практике. Верховный Суд РФ, утвердив обзор судебной практики освобождения от уголовной ответственности с назначением судебного штрафа (статья 76.2 УК РФ), снял ряд вопросов, относящихся к практике применения ст. 76.2 УК РФ. Это касается возможности применения рассматриваемой нормы к: преступлениям с формальным составом; составам преступления и ситуациям при отсутствии материального вреда; совокупности преступлений и др.

Но усмотреть единообразный подход апелляционных инстанций к взаимосвязанно применяемым ст. 76.2 и ч. 6 ст. 15 УК РФ на настоящий момент не представляется возможным.

В этой связи нелишним видится обращение к динамике подходов высшего судебного органа страны и теоретиков права к двум правовым институтам судебного штрафа и категориальности преступлений, а особенно к той ситуации, когда эти два правовых института пересекаются (взаимодействуют). При этом изменение категории преступления предшествует принятию решения по основаниям ст. 76.2 УК РФ.

Заслуживает внимание и отсутствие единой процессуальной формы, в рамках которой принимаются решения. Не единичны случаи, когда освобождение от уголовной ответственности по основаниям ст. 76.2 УК РФ после изменения категории преступления осуществляется постановлением (курсив наш - В.С. и Н.П.) суда в рамках дел об имущественных преступлениях. Но возникает ощущение, что при современной либеральной тенденции правоприменительная практика остановилась в полушаге от более частого применения, мягко говоря, этого не однозначного механизма и по тяжким преступлениям против личности. И если это случится, то размытыми окажутся принципы (в первую очередь - справедливости и законности) и иные фундаментальные положения уголовного права.

Тяжкими преступлениями признаются умышленные деяния, за совершение которых максимальное наказание, предусмотренное УК РФ, превышает пять лет и не превышает десяти лет лишения свободы, и неосторожные деяния, за совершение которых максимальное наказание, предусмотренное УК РФ, не превышает пятнадцати лет лишения свободы (ч. 4 ст. 15 УК РФ).

В пункте 1 Постановления Пленума ВС РФ № 10 от 15.05.2018 г. («О практике применения судами положений части 6 статьи 15 Уголовного кодекса Российской Федерации») указывается, что изменение категории преступления положительно влияет на решение целого ряда вопросов, связанных с правовыми последстви- 
ями осуждения: назначением вида исправительного учреждения, условно-досрочным освобождением и др.

Но в этом постановлении ничего не говорится о связи изменения категории преступления с возможностью последующего применения положений ст. 76.2 УК РФ. К тому же, решение о возможности применении положений пункта 6.1 части 1 ст. 299 УПК РФ принимается в итоговом документе, а именно в ходе разрешении судом вопросов при постановлении приговора (ст. 299 УПК РФ).

Вопрос об изменении категории преступления на менее тяжкую решается судом первой инстанции при вынесении обвинительного приговора по уголовному делу, рассмотренному как в общем, так и в особом порядке судебного разбирательства [19]. Изменение категории преступления возможно только после того, как осужденному назначено наказание с учетом предусмотренных УК РФ правил назначения наказания, при условии, что вид и срок назначенного наказания отвечают требованиям части 6 статьи 15 УК РФ [20].

Вместе с тем, пункте 10 Постановления Пленума ВС РФ № 10 от 15.05.2018 г. «О практике применения судами положений части 6 статьи 15 Уголовного кодекса Российской Федерации» говорится о том, что решение суда об изменении категории преступления с тяжкого на преступление средней тяжести позволяет суду при наличии оснований, предусмотренных статьями 75, 76, 78, 80.1, 84, 92, 94 УК РФ, освободить осужденного от отбывания назначенного наказания (курсив наш - Н.П., В.С.). В этих случаях суд постановляет приговор, резолютивная часть которого должна, в частности, содержать решения о признании подсудимого виновным в совершении преступления, о назначении ему наказания, об изменении категории преступления на менее тяжкую с указанием измененной категории преступления, а также об освобождении от отбывания назначенного наказания (пункт 2 части 5 статьи 302 УПК РФ). То есть, речь идет об освобождении от уголовного наказания, но не освобождении от уголовной ответственности, хотя и включает в себя две нормы УК РФ из главы 11 УК РФ, а именно ст. 75 и ст. 76 УК РФ.

В этой ситуации видится неопределенность (несогласованность, нарушение системности) положений пунктов 21-28 (Процессуальные особенности применения норм главы 11 УК РФ) Постановления Пленума Верховного Суда РФ № 19 от 27.06.2013 г. «О применении судами законодательства, регламентирующего основания и порядок освобождения от уголовной ответственности», и пункта 10 Постановления Пленума ВС РФ № 10 от 15.05.2018 г.
Коль скоро сложилась определённая практика применения положений ч. 6 ст. 15 УК РФ с последующим назначением меры уголовно-правового характера в виде судебного штрафа применительно к тяжким преступлениям, то выход из сложившейся ситуации видится по двум вариантам. С учётом различия между ними, уходящего в суть применяемых институтов, назовём эти подходы либерально-гуманистическим и собственно-правовым.

В соответствии с первым из них, в угоду практики, сложившейся наперекор принципам уголовного права, а нередко - и здравому смыслу, следует окончательно устранить последние препятствия для правоприменения. Видится возможным сделать это таким образом:

- изъять из перечня пункта 10 Постановления Пленума ВС РФ № 10 от 15.05.2018 г., регламентирующего возможность освобождения от наказания вследствие либерализации судом категории преступлений, указания на 75, 76 УК РФ и дополнить указанное постановление отдельным пунктом, В котором помимо статей 75 и 76 УК РФ прописать порядок применения ст. 76.2 УК РФ, а именно освобождение от уголовной ответственности;

- поскольку ходатайство о применении положений ч. 6 ст. 15 УК РФ с последующим назначением судебного штрафа по рассматриваемым в суде категориям тяжких преступлений может поступить только в стадии судебного следствия, применение положений пункта 24 Постановления Пленума Верховного Суда РФ № 19 от 27.06.2013 г. о возможности освобождения от уголовной ответственности вследствие изменения категории преступления на досудебной стадии исключается. Соответственно, в раздел Постановления Пленума Верховного Суда РФ № 19 от 27.06.2013 г. (Процессуальные особенности применения норм главы 11 УК РФ) необходимо внести дополнения. Эти изменения должны быть логически увязаны с главой 11 УК РФ и предлагаемыми нами изменениями в Постановление Пленума ВС РФ № 10 от 15.05.2018 г. В частности, В Постановления Пленума Верховного Суда РФ № 19 от 27.06.2013 г. следует прописать, что частным случаем освобождения от уголовной ответственности является решение о применении ст. 76.2 УК РФ после изменения судом категории преступления и освобождении от наказания.

Второй вариант, названный нами, собственно, правовым, предполагает обращение к фундаментальным положениям уголовного права и уголовного закона в рамках институтов судебного штрафа и категорий преступлений и дальнейшее исправление принятых законодательных конструкций. Напомним, что в док- 
трине уголовного права последних лет - это наиболее часто обсуждаемые институты. И если некоторые вопросы применительно к судебному штрафу к настоящему времени сняты усилиями ВС РФ, то интерес критиков к ч. 6 ст. 15 УК РФ никогда не снижался.

В частности, если ещё совсем недавно норма о судебном штрафе понималась как сугубо дискреционная [2, с. 220-223;21, с. 104-109], то понимание природы судебного штрафа и последовавшие разъяснения ВС РФ, данные в постановлении Пленума Верховного Суда РФ от 27.06.2013 N19 (ред. от 29.11.2016) «О применении судами законодательства, регламентирующего основания и порядок освобождения от уголовной ответственности», не относят норму о судебном штрафе к числу применяемых по усмотрению правоприменителя. Напомним, постановлением № 56 от ВС РФ от 29.11.2016 из постановления № 19 исключён п. 6, рассматривавший применение нормы о судебном штрафе исключительно как право суда, а в п. 27 постановление дополнено положением, согласно которому, если суд первой инстанции при наличии оснований, предусмотренных пунктом 3 части 1 статьи 24, статьями 25, 25.1, 28 и 28.1 УПК РФ, не прекратил уголовное дело и (или) уголовное преследование, то в соответствии со статьей 389.21 УПК РФ суд апелляционной инстанции отменяет обвинительный приговор и прекращает уголовное дело и (или) уголовное преследование.

Принципам справедливости, законности, а также единообразному применению норм УК РФ послужили разъяснения ВС РФ, данные в обзоре судебной практики освобождения от уголовной ответственности с назначением судебного штрафа (статья 76.2 УК РФ), утверждённом Президиумом Верховного Суда РФ 10 июля 2019 г. В частности, положена основа для единообразного применения нормы о судебном штрафе в ситуациях, связанных с преступлениями с формальным составом, совокупностью преступлений, в отсутствие реального материального вреда.

В целом в теории уголовного права к настоящему времени освобождение от уголовной ответственности в связи с назначением судебного штрафа воспринимается как позитивный уголовно-политический шаг с очевидным гуманистическим потенциалом. Однако, очевидны и «узкие места» этого правового института. В литературных источниках, на наш взгляд, заслуженно обосновывается необходимость ограничения применения судебного штрафа к некоторым категориям преступлений (террористической, экстремистской, сексуальной, в отношении несовершеннолетних и др. направленности) [10]; оспаривается возможность применения к полиобъектным преступлениям, совокупности преступлений [12, с.115-119].
Критики судебного штрафа как альтернативы уголовного наказания в качестве проблем называют также неясность фигуры «конечного бенефициара» судебного штрафа, что особенно важно с учётом практического «отстранения» потерпевшего от решения вопроса о применении ст. 76.2 УК РФ и высокой коррупционной составляющей [21, с. 104-109].

Иногда удивляет та лёгкость, с которой правоприменитель применяет решение о судебном штрафе. Что здесь: процессуальный интерес реального бенефециария, о чём предупреждают исследователи [24], или недооценка важности правоохраняемого объекта - сложно сказать. Вот пример следственно-судебной практики, который приводит исследователь, он же - руководитель следственного подразделения В.В. Медянцев: «В практике следственного управления распространены факты направления в суд уголовных дел с ходатайством о прекращении уголовного дела или уголовного преследования в отношении обвиняемого (подозреваемого) и назначении ему меры уголовно-правового характера в виде судебного штрафа при отсутствии по делу материального ущерба. ...Например, следователем Пермского межрайонного следственного отдела 23.01.2020 в суд в порядке, предусмотренном ст. 446.2 УПК РФ, направлено уголовное дело, возбужденное 06.11.2019 г. по признакам преступления, предусмотренного ч. 2 ст. 143 УК РФ, по факту нарушения «Ф», являющегося механиком автотранспортного цеха ООО «ПГС-Пермь», требований охраны труда, повлекшего по неосторожности смерть «В». В ходе допроса потерпевшая «Р» (дочь погибшего) пояснила, что к ней обратился подозреваемый «Ф», который в ходе беседы принес ей извинения, полностью признал вину в совершенном преступлении, раскаялся в содеянном, чем загладил причиненный преступлением вред. Иных претензий, в том числе материального характера, к «Ф» она не имеет. Постановлением суда от 20.01.2020 ходатайство следователя удовлетворено, в отношении «Ф» применена мера уголовно-правового характера в виде судебного штрафа в размере 60000 рублей» [13].

Выводы впечатляют: во-первых, оказывается, что одна «беседа» с родственником погибшего человека полномерный способ заглаживания вреда, во-вторых, руководитель следственного подразделения называет довольно широкий спектр преступлений, когда применяется судебный штраф, среди которых - преступления, объектами которых являются половая неприкосновенность личности и даже жизнь человека (пусть хотя бы и в качестве дополнительного объекта).

Таким образом, судебный штраф как междисциплинарный институт на настоящем этапе развития российского законодательства и следственно-судебной 
практики далёк от совершенства и предполагает взвешенный подход правоприменителя.

Прежде чем дать оценку практике освобождения от уголовной ответственности с применением судебного штрафа после изменения категории преступления с тяжкого на категорию средней тяжести, обратимся к теоретико-правовым аспектам ч. 6 ст. 15 УК РФ.

«Миной замедленного действия», заложенной в и так уже пошатнувшееся в результате многочисленных, часто бессистемных и поспешных изменений «здание» уголовного закона, назвала в своё время профессор юридического факультета МГУ Н. Крылова законопроект об изменении категорий преступлений и праве суда изменять категорию преступления [8]. Среди последствий такого «взрыва мины» учёный особо отмечает сложно прогнозируемые правовые последствия, связанные, в частности, с обратной силой закона и ряд других, но самое главное - новелла ставит под сомнение само понятие общественной опасности преступления.

Теперь уже со всей очевидностью к таковым последствиям следует отнести правоприменительную практику, когда тяжкое преступление суд переводит в разряд преступлений средней тяжести, а затем применяются положения ст. 76.2 УК РФ, и лицо освобождается от уголовного наказания по норме об освобождения от уголовной ответственности. Особенно неприемлемы такие правовые и конструкции и обеспечивающие их «процессуальные лабиринты» в двух встречающихся случаях: 1) когда виновное лицо освобождается от ответственности за тяжкое преступление против личности (например, от ответственности за преступление, предусмотренное ч. 1 ст. 111 УК РФ) после назначенного наказания; 2) когда окончательное решение принимается в форме постановления суда, т.е. даже без соблюдения минимального процессуального «приличия».

Наиболее решительно и последовательно критиковал изменения в институте категорий преступлений, внесённые Федеральным законом от 7 декабря 2011 г. № 420 проф. В. Малков. В частности, ч. 6 ст. 15 УК РФ подвергалась критике в связи с тем, что это законоположение устанавливает необоснованно широкие пределы усмотрения для суда (судьи) и возможность необоснованного применения исключений из общих правил, а следовательно,-и злоупотреблений по этому вопросу (т.е. содержит коррупциогенные факторы) [11]. Новеллу уголовного закона, предоставившую суду право изменять категорию преступления, этот учёный считает неприемлемой (а точнее - ошибочной), утверждает, что от неё следует по возможности быстрее отказаться, поскольку суд (судья) наделяется не свойственными ему полномочиями - изменять установленную федеральным законом категорию тяжести совершённого преступления, что противоречит ст. 10 Конституции РФ, в соответствии с которой государственная власть в Российской Федерации осуществляется на основе разделения на законодательную, исполнительную и судебную, а органы законодательной, исполнительной и судебной власти самостоятельны [11]. Положения ч. 6 ст. 15 УК РФ подверглись обоснованной критике этого учёного и потому, что они: дают судам (судьям) право выходить за пределы полномочий по осуществлению правосудия, т.е. игнорируют принцип законности, передавая функции законодателя суду; не соответствуют антикоррупционным требованиям, предъявляемым к нормативно-правовым актам.

Значение категории преступления в российском уголовном законодательстве переоценить сложно. Категориальность транслирована в значительное число правовых норм (ст. 18, 30, 35, 46, 48, 53, 53.1, 56, 57, $58,59,61,69,73,74,75,76,76.2,78-80.1,83,86,88,90$, 92, 93, 95 УК РФ). Отсюда просматриваются возможные «масштабы» влияния произвольного подхода к вопросу об изменении категории преступления на правоприменительную практику.

В этом контексте резонны, например, наблюдения и выводы Л.Ю.Лариной: «Исходя из того, что категория преступления изменяется уже при назначенном наказании, такая измененная категория преступления не может учитываться в ст. 46, 48, 53, 53.1, 56, 57, 59, 61, $69,75,76,88,90$ УК РФ». Однако, констатирует этот учёный, судебная практика пошла по иному пути. Высшая судебная инстанция указала, что изменение категории преступления влияет в числе прочего на исчисление сроков давности, определение вида рецидива, изменение режима отбывания наказания, освобождение от уголовной ответственности в связи с примирением с потерпевшим. Отсюда следует, что Верховный Суд РФ допускает возможность применения всех перечисленных статей УК РФ в случае изменения судом категории преступления [9]. На основе предпринятого анализа Л.Ю. Ларина приходит к Выводу о том, что ч. 6 ст. 15 УКРФ в нынешней редакции является чрезвычайно неудачной нормой, которая, с одной стороны, создает благоприятные условия для нарушения основополагающих принципов уголовного права, а с другой - выступает серьезным коррупциогенным фактором благодаря отсутствию четких критериев изменения категории преступлений. Этот исследователь видит два пути выхода из ситуации. Во - первых, конкретизировать в законе четкие критерии, позволяющие суду изменить категорию преступления, а также прямо указать, какие правовые последствия несет такое изменение. Однако это 
позволит лишь смягчить ситуацию, а не исправить ее, поскольку сущность образовавшейся проблемы не изменится. Во-вторых, можно пойти по наиболее справедливому, с точки зрения права, пути и исключить ч. 6 из ст. 15 УК РФ [9].

Предметом исследования в рамках проблематики изменения категории преступлений среди прочего стали и необходимые условия применения ч. 6 ст. 15 УК РФ

Напомним, что в качестве основания изменения категории преступления законодателем указаны фактические обстоятельства преступления, степень его общественной опасности, наличие смягчающих обстоятельств и отсутствие отягчающих обстоятельств. Т.В. Николаева справедливо замечает: «Какие фактические обстоятельства должны быть учтены судом, законодатель не разъясняет, а вопрос об учете степени общественной опасности представляется еще более проблематичным, поскольку она учитывается законодателем в определении категории преступления наряду с характером общественной опасности (ч. 1 ст. 15 УК $P Ф) »[14]$.

По утверждению Ю.Е. Пудовочкина, понятие «фактические обстоятельства преступления» не имеет ни нормативной, ни однозначной доктринальной трактовки [17].

В другой работе Ю.Е. Пудовочкин и Н.В. Генрих замечают: «разделить» фактические обстоятельства и степень опасности как самостоятельные критерии оценки преступления невозможно по определению, поскольку на основе фактически обстоятельств как раз и происходит оценка степени общественной опасности содеянного. Таким образом, единственным основанием для принятия решения об изменении категории выступает именно степень общественной опасности совершенного преступления [18]. Согласимся с этим и добавим, что фактические обстоятельства совершенного преступления являются носителем свойств, определяющих степень общественной опасности.

Несложно заметить, что законодательные критерии изменения категории преступления определены недостаточно чётко.

Включение в ч. 6 ст. 15 УК РФ категории «фактические обстоятельства дела» в качестве условия её применения обусловила востребованность её трактовки высшим судебным органом страны для нижестоящих судов.

Раскрывая содержание этой категории в п. 2 Постановления № 10 от 15.05.2018 г., Пленум ВС РФ рекомен- дует судам принимать во внимание способ совершения преступления, степень реализации преступных намерений, роль подсудимого в преступлении, совершенном в соучастии, вид умысла либо вид неосторожности, мотив, цель совершения деяния, характер и размер наступивших последствий, а также другие фактические обстоятельства преступления, влияющие на степень его общественной опасности. Вывод о наличии оснований для применения положений части 6 статьи 15 УК РФ может быть сделан судом, если фактические обстоятельства совершенного преступления свидетельствуют о меньшей степени его общественной опасности.

Сложно разделить оптимизм исследователей, выражающих надежду на то, что недостаток правового регулирования в ч. 6 ст. 15 УК РФ будет компенсирован необширной практикой её применения. Так, Н. Скрипченко резюмирует: «Подчеркивая значимость анализируемого документа, установившего пределы вмешательства судебной власти в область правотворчества, вряд ли можно разделить мнение о том, что принятие Постановления повлечет широкую практическую реализацию ч. 6 ст. 15 УК РФ» [26].

Но только ли в количестве случаев применения этих спорных положений УК РФ и процессуальных процедур кроется проблема?

С определённой оговоркой можно согласиться с утверждением исследователей о том, что в целом возможность понижения категории преступления направлена на улучшение положения осужденного при наличии к тому оснований [5].

Однако участившиеся случаи ничем не оправданного применения «связки» положений ч. 6 ст. 15 УК РФ и ст. 76.2 УК РФ применительно к освобождению от уголовной ответственности за тяжкие преступления с применением сомнительных правовых конструкций и столь же неубедительных процессуальных «горок», не прописанных в законе, приводят нас к мысли о том, что предсказанный исследователями взрыв «бомбы замедленного действия» все же случился.

Попытки найти альтернативное отношение в научной литературе к положениям ч. 6 ст. 15 УК РФ показывают, что исследователи здесь разделились на три группы: 1) авторы с однозначной критика изменений категориальности преступлений (их большинство); 2) немногочисленные сторонников, в целом поддерживающих законодательное нововведение (главным образом потому, что за основу делений преступлений на категории они предлагают брать не санкции норм, а назначенное наказание) [6]; 3) авторы, предлагающие определённые рекомендации для более безболезнен- 
ной адаптации рассматриваемой нормы в правоприменительную практику. Например, А. Хайдаров делает это, приводя случаи из судебной практики, когда само деяние не свидетельствует о наличии фактических обстоятельств, дающих для применения ч. 6 ст. 15 УК (несколько хорошо подготовленных групповых краж с распределением ролей), однако суд, не называя фактические основания, учитываемые при применении ч. 6 ст. 15 УК РФ, изменяет категорию преступления на более мягкую. Тем не менее и этот учёный не обходится без вывода, оптимистическим который назвать никак нельзя: «Положениями ч. 6 ст. 15 УК и п. 6.1 ч. 1 ст. 299 УПК расширяются пределы судейского усмотрения настолько, что контролировать такую практику имеющимися процессуальными средствами невозможно. Судейское усмотрение является имманентным элементом правоприменительной деятельности судьи (суда), но п. 61 ч. 1 ст. 299 УПК создаёт судье (суду) простор для произвола» [30].

В контексте сказанного, повышенный исследовательский интерес вызывает позиции законодателя, теоретиков и практиков на случаи применения нормы о судебном штрафе после изменения категории преступления с тяжкого на средней тяжести.

По общему правилу, не связанному с возможностью дальнейшего освобождения от уголовной ответственности, такое изменение категории преступления возможно. Напомним об условиях для этого: наличие соответствующих фактических обстоятельств, а также обстоятельств, смягчающих наказание и отсутствие обстоятельств, отягчающих наказание, при том, что назначенное наказание не превышает пяти лети лишения свободы, а категория понижается не более, чем на одну ступень. Кроме того, судебный штраф (ст. 76.2 УК РФ) как мера уголовно-правового характера может быть применена судом также при наличии строго определённых условий: распространяется на случаи совершения преступления небольшой и средней тяжести впервые, если оно возместило ущерб или иным образом загладило причинённый преступлением ущерб.

Буквальное толкование последней нормы исключает возможность применения судебного штрафа к случаям совершения тяжких преступлений.

П. 10 ПВС РФ № 10 от 15.05.2018 г., регламентирующий право суда после изменении категории преступления с тяжкого на преступление средней тяжести, освободить лицо от наказания по основаниям статей 75, 76, 78, 80.1, 84, 92, 94 УК РФ - пример необоснованно широкого судебного толкования правовых норм, в котором нашли своё выражение: смешение функций ветвей власти, принятие на себя судами функции законодате- ля, нарушение системности права, смешение правовых институтов (например, освобождение от ответственности и освобождения от наказания), нарушение стадийности уголовного процесса, произвольное толкование норм права, а в результате - существенные нарушения принципа справедливости и равенства граждан перед законом. Известное выражение из фильма «Джельтмены удачи»: «Украл, выпил - в тюрьму! Украл, выпил в тюрьму!» может смениться на другое, смыслом которого станет: «Украл - заплати штраф - свободен» или, что ещё хуже, но уже реальное: «Покалечил - заплати штраф - свободен».

Уместно проанализировать взгляды исследователей на возможность распространения судебного штрафа на тяжкие преступления (после понижения категории). Их также условно можно разделить на три группы.

Небольшая часть научной аудитории считает возможным освобождать от уголовной ответственности в связи с совершением впервые некоторых тяжких преступлений (например, предусмотренных ч. 1 ст. 111 , ч. 1 ст. 131, ч.ч. 3, 4 ст. 158, ч.ч. 1, 2 ст. 162 УК PФ) [3]. Обращает на себя внимание оправдание такого подхода при минимуме или в отсутствие аргументов столь кардинальных решений [7]. Приветствуя такую практику с минимальным обоснованием (результаты опроса судей), С.П. Андреев тем не менее заключает, что для освобождения виновного от наказания при назначении судебного штрафа сегодня нет законных оснований. А применение уголовного закона по аналогии недопустимо. В связи с этим необходимо рассмотреть вопрос о внесении соответствующих дополнений в уголовное законодательство в части возможности применять судебный штраф и при освобождении от наказания [1].

Ряд исследователей констатируют распространение судебного штрафа на категорию тяжких преступлений без выражения собственных оценок [23].

В большей же части исследований высказывается отрицательное отношение к освобождению от уголовной ответственности по основанию назначения судебного штрафа после изменения категории преступления (с тяжкой на средней тяжести) ввиду отсутствия правовых оснований, несоответствия такого подхода основополагающим принципам уголовного права и очевидной коррупциогенности [4; 9].

Выше уже упоминались предложения и вовсе сузить перечень преступлений небольшой и средней тяжести, когда в отношении виновных возможно применение судебного штрафа. Учёт в таком контексте тяжких преступлений исключается. 
Предпринятое исследование позволило нам сформулировать следующие выводы.

1. Законодательная практика последнего десятилетия обнаруживает противоречивые новеллы в сфере противодействия преступности. Сюда относятся результаты нормотворчества, нашедшие своё место в институтах судебного штрафа и категорий преступлений (ст. 76.2 и ст. 15 УК РФ).

2. Как следствие, в российском уголовном судопроизводстве в последние годы сложился, по существу, нигилистический подход, когда, в нарушение конституционного принципа разделения властей, межотраслевых и внутриотраслевых принципов (справедливости, равенства), да и здравого смысла, лицо, виновное в тяжком преступлении, в том числе и против личности, и, по существу осуждённое за него с определением наказания, тем же приговором суда освобождается от уголовной ответственности в результате изменения категории преступления.

3. Судебный штраф как иная мера уголовно-правового характера на настоящем этапе развития российского законодательства и следственно - судебной практики далёк от совершенства и предполагает взвешенный подход правоприменителя.

4. Невнятное правовое основание приводит к различным процессуальным решениям, когда при освобождении от уголовной ответственности за тяжкие преступления, переведённые судом в категорию преступлений средней тяжести, наряду с приговорами практикуются и постановле- ния суда (в последнем случае, разумеется, без промежуточного наказания), что несовместимо с правилами изменения категорий преступлений.

5. В некоторых случаях встречается и сомнительная квалификация действий виновного лица, не исключено, что с перспективой на конечный результат, для дальнейшего соответствия требованию ч. 6 ст. 15 УК РФ о допустимости изменения категории преступления на одну ступень.

6. В зависимости от воли законодателя и правоприменителя в качестве выходов из ситуации видятся два варианта: а) по «программе-минимум» из Постановления Пленума Верховного Суда Российской Федерации от 15 мая 2018 г. N10 г. Москва «О практике применения судами положений части 6 статьи 15 Уголовного кодекса Российской Федерации» следует исключить п. 10 о праве суда освобождать осуждённое лицо от наказания по основаниям ст.ст. 75, 76, 78, 801, 84, 92, 94 УК РФ; б) более приемлемый путь - исключение из УК РФ ч. 6 ст. 15 УК РФ и запрет на применение ст.ст. 75, 76, 76.1, 76.2 УК РФ после изменения категории преступления с тяжкого на средней тяжести. 7.Законодательные и правоприменительные новеллы последних лет требуют актуализации Постановления Пленума Верховного Суда РФ № 55 от 29 ноября 2016 г. (О судебном приговоре). В частности, это касается учёта тех вариантов окончательного судебного решения, когда оно сопряжено с последующей «трансформацией» наказания в судебный штраф.

\section{ЛИТЕРАТУРА}

1. Андреев С.П. К вопросу об изменении категории преступления судом при освобождении от уголовной ответственности с назначением судебного штрафа// Вопросы российского и международного права. - 2021. - Т. 11.-№ 3-1.- С. 158-166.

2. Белик Ю.С. Особенности реализации уголовно-правовых норм о судебном штрафе// Уголовная политика и культура противодействия преступности: сборник статей международной научно-практической конференции 30 сент. - 2016 г. - Т. 1. — Краснодар. — 2016. - C. 220-223.

3. Владимирова 0.А. Освобождение от уголовной ответственности в связи с примирением с потерпевшим: автореф. дис. ... к.ю.н.- Самара.2015. - $22 \mathrm{C}$.

4. Долотов Р.О. Уголовно-правовые последствия применения судом ч. 6 ст. 15 УК РФ// Вестник Московского университета. Серия 11: Право. — 2015. № 4.- - $.60-72$.

5. Епихин А.Ю. Расширение полномочий суда на понижение категории преступления: уголовно-правовой и уголовно-процессуальный аспекты//Юридическая наука и правоохранительная практика.-2012. — № 1 (19). - С. 105-108.

6. Жалинский А.Э. Уголовное право в ожидании перемен: теоретико-инструментальный анализ.— М., 2014. — С. 307.

7. Зарубин А.В. Некоторые проблемы судебной практики освобождения от уголовной ответственности с назначением судебного штрафа// Уголовная политика и правоприменительная практика: сборник материалов VIII-й Международной научно-практической конференции. Санкт-Петербург, 2020.-C. 107-113.

8. К Крылова Н. К вопросу о гармонизации и гуманизации уголовного закона//Уголовное право. — 2016. — № 6. — С. 26 -34.

9. Ларина Л.Ю. К вопросу об изменении судом категории преступления//Юридическая наука. — 2013. — № 2.— С. 56-59.

10. Луценко Н.С. Основания и условия освобождения от уголовной ответственности с назначением судебного штрафа в теоретическом и прикладном контекстах// Вопросы российского и международного права. - 2019.—- Т. 9. — № 4-1.- С. 332-340.

11. Малков В. Право суда на изменение категории преступления//Законность.— 2013.— № 11 (949).—C. $36-39$. 
12. Мансурова С.И. Некоторые спорные вопросы применения судебного штрафа в уголовном законодательстве РФ//Современные проблемы борьбы с преступностью: перспективы и пути решения: сборник статей Всеросс. научно-практической конференции студентов, аспирантов и молодых ученых. Горно-Алтайск, 2018.-С. 115-119.

13. Медянцев В.В. Особенности практического применения меры уголовно-правового характера в виде судебного штрафа// Пенитенциарная система и общество: опыт взаимодействия: сборник материалов VIII Международной научно-практической конференции. Пермь, ФКОУ В0 Пермский институт ФСИН России, 2021. - С. 35-37.

14. Николаева Т.В. Теоретические и правовые аспекты изменения категории преступления// Вестник Уфимского юридического института МВД России. 2016. 一 № 4.- С. 24-27.

15. Обзор судебной практики освобождения от уголовной ответственности с назначением судебного штрафа (статья 76.2 УК РФ) (утв. Президиумом Верховного Суда РФ 10 июля 2019 г.) [Электронный ресурс]. URL: https://www.vsrf.ru/documents/all/28088/.(дата обращения: 19 июля 2021 г.).

16. Приговор по уголовному делу № 1-83/2020 г.// Официальный сайт Благоварского межрайонного суда Республики Бошкортостан. [Электронный реcypc]. URL: http://blagovarsky.bkr.sudrf.ru/ (дата обращения 09.06.2021 г.).

17. Пудовочкин Ю.Е. 0 грядущих изменениях уголовного закона // URL: http://sartraccc.ru/i.php?oper=read_file\&filename=Pub/pudovochkin(09-11-11). htm. (дата обращения: 19.07.2021).

18. Пудовочкин Ю.Е., Генрих Н.В. Изменение категории преступления судом: теоретико-прикладной анализ//Научный вестник Омской академии МВД России. - 2019. — № 2(73).-С. 3-10.

19. Пункт 5 Постановления Пленума ВС РФ № 10 от 15.05 .2018 г.

20. Пункт 8 Постановления Пленума ВС РФ № 10 от 15.05 .2018 г.

21. Пятакова Н.С., Рябинин А.Г. Вопросы реализации меры уголовно-правового характера в виде судебного штрафа: проблемы и пути их решения// Современные тенденции развития науки и технологий. - 2016. № 11-7.—C. 104-109.

22. Репьева А.М. Изменение категории преступления на менее тяжкую: взгляд через призму принципа справедливости// Вестник Саратовской государственной юридической академии. - 2019. — № 3 (128). - С. 208-215.

23. Решетняк В.И. Принятие судами решений об изменении категории преступлений на менее тяжкую//Законность. - 2016. — № 9 (983). - С. 38-41.

24. Рыжаков А.П. Новое основание прекращения дела и последствия его введения // Уголовный процесс. — 2016.— № 10.—C. 52-58.

25. Сводные статистические сведения о деятельности федеральных арбитражных судов за 2020 год// Судебный департамент при Верховном Суде Российской Федерации [Электронный ресурc].URL: http://www.cdep.ru/index.php?id=79. (дата доступа: 21 июля 2021 г.).

26. Скрипченко Н. Вопросы изменения категории преступлений в Постановлении Пленума Верховного Суда// Уголовное право. - 2018. - № 5.C. 60-63.

27. Уголовное дело № 1-142/2020 (1-770/2019;). https://piatigorsky — stv.sudrf.ru/modules.php?name=sud_delo\&srv_num=1\&name_ op=doc\&number=134265253\&delo_id=1540006\&new=0\&text_number=1 (дата обращения 09.06.2021 г.).

28. Уголовное дело № 1023/2020//0фициальный сайт Кронштадтского районного суда Санк-Петербурга. [Электронный pecypc].URL: https://krn — spb. sudrf.ru/modules.php?name=sud_delo\&srv_num=1\&name_op=doc\&number=393605397\&delo_id=1540006\&new=0\&text_number=1 (дата 06ращения: 19.07.2021 г.).

29. Уголовное дело № 1-33/2014 г.// Официальный сайт Красносулинского районного суда Ростовской области. [Электронный ресурс]. URL: https:// krasnosulinsky — ros.sudrf.ru. (дата обращения: 19.06 .2021 г.).

30. Хайдаров А. Право суда изменять категорию преступления на более мягкую//Законность. — 2015. — № 2 (964). - С. 38-42.

(с Сафонов Владимир Николаевич ( svn205@gmail.com ), Петровский Николай Казимирович ( pnkspb5@mail.ru ).

Журнал «Современная наука: актуальные проблемы теории и практики» 